\title{
Assessing Genetic Diversity Based on Gliadin Proteins in Aegilops cylindrica Populations from Northwest of Iran
}

\author{
Toraj KHABIRI, Rasool ASGHARI-ZAKARIA*, Nasser ZARE, Omid SOFALIAN \\ University of Mohaghegh Ardabili, Department of Agronomy and Plant Breeding, Ardabil, Iran; r-asghari@uma.ac.ir (*corresponding author)
}

\begin{abstract}
Wild wheat progenitors served as a valuable gene pool in breeding perspectives. In this respect, gliadins could be an important tool in assessing genetic variability as protein markers. Thus, genetic diversity of gliadin protein patterns in seventeen populations of Aegilops cylindrica collected from northwest of Iran were investigated using acid polyacrylamide gel electrophoresis. Results showed that the highest number of bands in the electrophoregrams were related to the $\omega$ type of geliadins. Conversely, the lowest number of bands were pertained to the $\beta$ type of gliadins. Genetic diversity between populations was greater than within population variation. Assessment of total variation for the three gliadin types indicated that the highest total variation was related to $\beta$ type while, the lowest one was belonged to $\omega$ type. Cluster analysis using complete linkage method divided populations into two separated groups in which genetic diversity does not follow from geographical distribution.
\end{abstract}

Keywords: Aegilops cylindrica, A-PAGE, genetic variation, gliadins

\section{Introduction}

Aegilops cylindrica is a winter annual autogamous, allotetraploid (genome formula: $\mathrm{C}^{c} \mathrm{C}^{c} \mathrm{D}^{c} \mathrm{D}^{\mathrm{c}}, 2 \mathrm{n}=4 \mathrm{x}=28$ ) grass, with long slender spikes. Studies identified that $A$. caudata $\mathrm{L} .(2 \mathrm{n}=2 \mathrm{x}=14, \mathrm{CC})$ as the donor of the $\mathrm{C}^{\mathrm{c}}$ genome and $A$. tauschii Coss. $(2 \mathrm{n}=2 \mathrm{x}=14, \mathrm{DD})$ as the donor of the $\mathrm{D}^{c}$ genome of this species. Its cytoplasm has been also donated from A. tauschii (Johnson, 1967; Tsunewaki, 1996). It shares the $D$ genome with wheat, and interspecific hybrids between the two species occur under natural field conditions (Guadagnuolo et al., 2001; Mallory-Smith et al., 1996; Zemetra et al., 1998).

Jointed goatgrass (A. cylindrica) has been identified as a useful but under-utilized source for wheat improvement. It has been reported that this species have important traits such as salt tolerance (Farooq et al., 1992), Hessian fly resistance (El Bouhssini et al., 1998), snow mold resistance and freezing tolerance (Iriki et al., 2001).

Gluten, the main storage protein in cereals, comprised of gliadin and glutenin (Carillo et al., 1990). Between storage proteins, gliadins, because of easy extraction and analysis by electrophoresis and high level of genetic diversity, attracted many concerns as biochemical markers for estimation of diversity among populations (Kenzewic et al., 1998). These subunits with molecular weight of 28-70 $\mathrm{kDa}$ (Payne et al., 1987) are usually alcohol-soluble monomeric proteins which are divided into four $\omega \gamma \beta$ and $\alpha$ groups based on their electrophoretic mobility. Among these regions, the $\omega$ have low cystein content while the others are cystein-rich, and their amino acid composition is different from other gliadins. The $\gamma$-gliadins are different from $\alpha$ - and $\beta$-gliadins in the amount of aspartic acid, methionine, proline, phenilalanine, tyrosine and tryptophan (Bietz et al., 1977). All gliadins have the low ionic amino acids such as arginine, histidine, lysine, and free carboxylic groups of aspartic acid and glutamic acid. In addition, gliadins can be classified according to their $\mathrm{N}$-terminal amino acid sequence (Gianibelli et al., 2001).

In wheat, the genes coding the gliadin proteins are located on the short arms of the first (Gli-A1, Gli-B1, Gli$D 1$ ) and sixth (Gli-A2, Gli-B2, Gli-D2) homoeologous groups. Gli-1 genes code for all the $\omega$ - and most of the $\gamma$-gliadins while Gli-2 genes for all the $\alpha$-, most of the $\beta$-, and some of the $\gamma$-gliadins (Metakovsky et al., 1984). The $\gamma$ -45 band of gliadin related to high gluten quality, whereas, the $\omega-38$ and $\gamma-42$ bands related to moderate and low gluten quality, respectively (Rashed et al., 2007).

Northwest of Iran is centre of origin and diversity for Aegilops species including A. cylindrica. However, genetic variation of different populations grown in this region is not studied in detail. The aim of present investigation was the study of gliadin proteins diversity in local populations of $A$. cylindrica from northwest of Iran to aid the subsequent studies to introgression from this species and enrich the wheat gene pool.

\section{Materials and methods}

\section{Plant material}

In this study, 17 populations of $A$. cylindrica collected from the northwest of Iran together with wheat cultivar ('Bezostaya' as standard), were evaluated with five plant (sample per populations) for each population (Tab. 1). 
110

\section{Protein analysis}

Extraction and electrophoretic separation of gliadin proteins was done according to the standard Acid-PAGE method described by Metakovsky and Novoselskaya (1991) with $8.5 \%$ gel concentration.

Single grains of each population, after removing embryo by razor blade, were crushed by minimortor and the flour was transferred to Eppendorf tubes, separately. Then, $150 \mu \mathrm{l}$ of ethanol $70 \%$ was added to the flour and the mixture was incubated at room temperature for $30 \mathrm{~min}$. After the centrifuging at 10000 ppm for 5 min, supernatant was transferred to an Eppendorf tube containing the equal volume of sucrose solution in $5.1 \mathrm{mM} \mathrm{Al-lactate}$ buffer, $\mathrm{pH}=3.1$. After the adding a minute quantity of pyronine (as marker) to the mixture, 5-7 $\mu \mathrm{l}$ of each ones were loaded into lanes. Electrophoresis was carried out at a constant voltage of $220 \mathrm{~V}$ for $10 \mathrm{~min}$, followed by $550 \mathrm{~V}$ for $2-3 \mathrm{~h}$ at a constant temperature of $14^{\circ} \mathrm{C}$.

\section{Data analysis}

The data obtained from Acid-PAGE was scored for the presence (1) or absence ( 0 ) of the bands and entered as a binary data matrix. Based on the results of electrophoretic band spectra, similarity index of simple matching coefficient was calculated for all possible pair of populations. The similarity matrix thus generated and used to construct the dendrogram using the complete linkage or furthest neighbours method in cluster analysis using NTSYS pc 2.0 software. Nei's (1978) gene diversity within and among populations was estimated using Popgene 1.32 software.

\section{Results and discussion}

Results showed that the C3 population had the most gliadin bands, with 16 bands, whereas the least gliadin

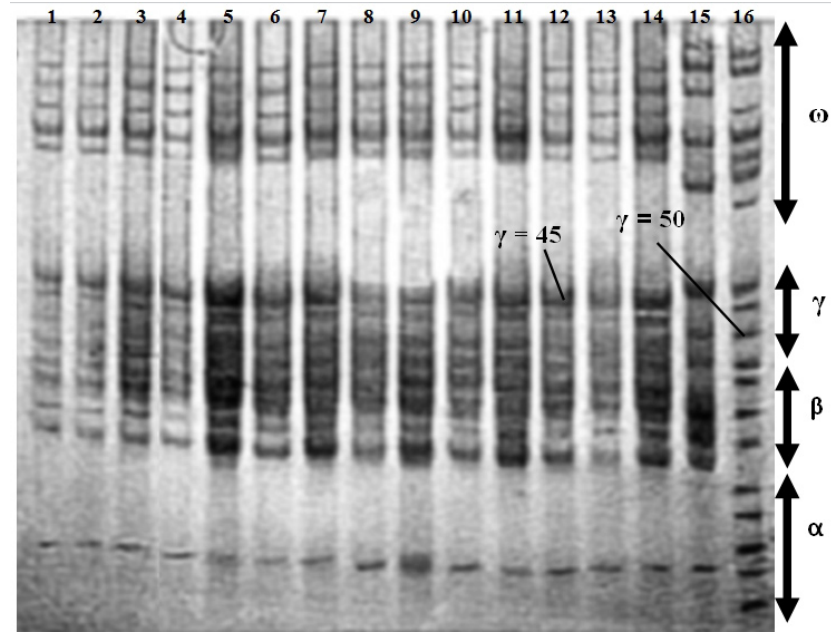

Fig. 1. Example of electrophoretic patterns of gliadin proteins in Bezostaya and the some populations of $A$. cylindrica. lanes 1 to 14 are various populations of $A$. cylindrica. lane 15: landrace wheat and lane 16: Bezostaya (as standard)

bands were observed in the C8 population, with 13 bands (Tab. 2). In some of the populations, just a fair band in $\alpha$ region was observed (Fig. 1, Tab. 2). However, Gregova et al. (2011) showed that $A$. cylindrica lacks the $\alpha$ region, which is in contrast with our finding. This may be due to different genotypes used in this study or different method for electrophoresis.

In the $\beta$ region, the highest number of bands were observed in the $\mathrm{C} 3, \mathrm{C} 4, \mathrm{C} 6$ and $\mathrm{C} 7$ populations with five bands, while, the lowest number of bands was observed in the $\mathrm{C} 8$ population with three bands. In this region, the highest amount of within population diversity (0.15) observed for the $\mathrm{C} 4$ and $\mathrm{C} 9$ populations. However, a number of populations did not show any within population diver-

Tab. 1. Locations of different populations of $A$. cylindrica used in this study

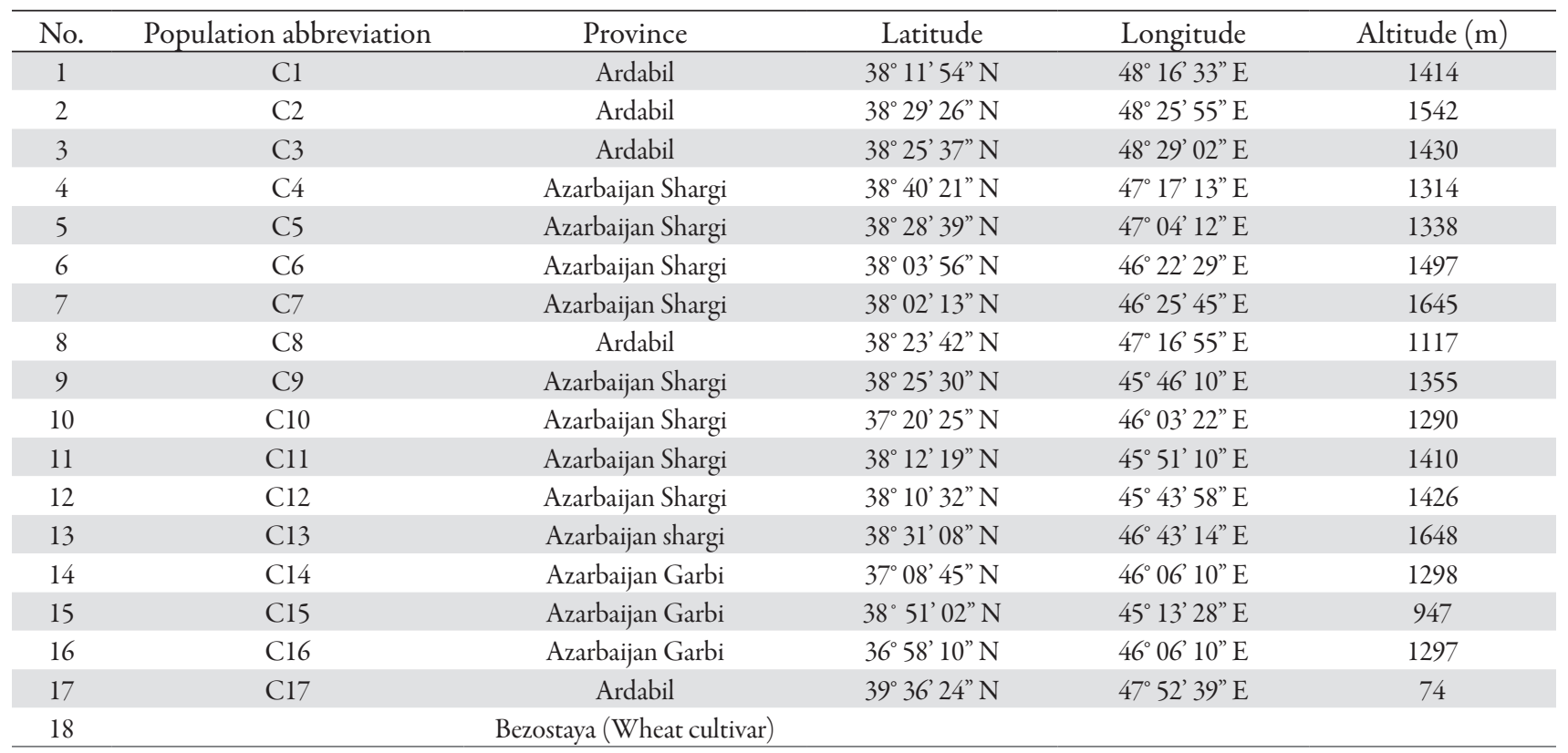


Tab. 2. Number of bands and Within population genetic diversity in gliadin bands of $A$. cylindrica

\begin{tabular}{|c|c|c|c|c|c|c|c|c|}
\hline \multirow{2}{*}{ Population abbreviation } & \multicolumn{4}{|c|}{ Number of bands } & \multicolumn{4}{|c|}{ Within population variation } \\
\hline & $\alpha$ & $\beta$ & $\gamma$ & $\omega$ & $\alpha$ & $\beta$ & $\gamma$ & $\omega$ \\
\hline $\mathrm{Cl}$ & 1 & 4 & 4 & 5 & 0 & 0 & 0.075 & 0.075 \\
\hline $\mathrm{C} 2$ & 1 & 4 & 5 & 5 & 0 & 0.075 & 0.075 & 0.075 \\
\hline C3 & 1 & 5 & 5 & 5 & 0 & 0.075 & 0 & 0 \\
\hline $\mathrm{C} 4$ & 1 & 5 & 4 & 5 & 0 & 0.15 & 0.075 & 0 \\
\hline C5 & 1 & 4 & 5 & 5 & 0 & 0 & 0.225 & 0 \\
\hline C6 & 0 & 5 & 5 & 5 & 0 & 0.075 & 0 & 0 \\
\hline C7 & 0 & 5 & 5 & 4 & 0 & 0 & 0 & 0 \\
\hline C8 & 1 & 3 & 4 & 5 & 0 & 0 & 0.075 & 0 \\
\hline C9 & 1 & 4 & 5 & 5 & 0 & 0.15 & 0.075 & 0.075 \\
\hline C10 & 1 & 4 & 5 & 5 & 0 & 0.075 & 0 & 0 \\
\hline C11 & 0 & 4 & 5 & 5 & 0 & 0 & 0.075 & 0 \\
\hline $\mathrm{C} 12$ & 1 & 4 & 4 & 5 & 0 & 0 & 0.15 & 0.075 \\
\hline $\mathrm{C} 13$ & 1 & 4 & 4 & 5 & 0 & 0 & 0 & 0.075 \\
\hline C14 & 1 & 4 & 4 & 5 & 0 & 0 & 0.075 & 0.075 \\
\hline C15 & 1 & 4 & 5 & 5 & 0 & 0.075 & 0.075 & 0.15 \\
\hline $\mathrm{C} 16$ & 1 & 4 & 5 & 5 & 0 & 0 & 0.075 & 0 \\
\hline $\mathrm{C} 17$ & 1 & 4 & 5 & 5 & 0 & 0.075 & 0.075 & 0.075 \\
\hline Mean & & & & & 0 & 0.0441 & 0.0662 & 0.0397 \\
\hline
\end{tabular}

sity in this region that it would be as a result of selection fixation of some alleles in this respects (Tab. 2).

In the $\gamma$ region, except for six populations $(\mathrm{C} 1, \mathrm{C} 4, \mathrm{C} 8$, $\mathrm{C} 12, \mathrm{C} 13$ and $\mathrm{C} 14$ ) which showed four bands, the others showed five bands. The C5 population showed the highest within population diversity $(0.225)$.

In the $\omega$ region, all of the populations showed five bands except for the $\mathrm{C} 7$ population with four bands in this region. The highest within population diversity $(0.15)$ was observed in the $\mathrm{C} 15$ population and other populations did not show any within population variation or a slight variation in this region (Tab. 2). The most bands of the $\omega$ region are located in $\mathrm{D}$ genome of $A$. cylindrica (Kozub et al., 2003, 2004), therefore it can be used in improvement the bread making quality of wheat through chromosome manipolation and hybridization techniques.

It was observed that the mean amount of within population diversity was greater for $\gamma$ region, even though, was slight for all of regions ( $\mathrm{Tab} 2$ ). This indicating that there was little genetic variation among plants in the same population. However, The genetic diversity among populations was greater than within populations which was greater for the $\beta$ region (Tab. 3). Assessment of total variation for the three regions indicated that the highest total variation was related to the $\beta$ region while, the lowest one was belonged to $\omega$ region. It can be concluded that there were only a limited variation among northwest Iranian jointed goatgrass populations considering gliadin proteins. This limit intraspecific genetic variation could be useful in accession determination (Tab. 3). Limited genetic diversity in seed storage proteins among different populations was also reported by Farkhari et al. (2007) and Vorosvary et al. (2000), also Isozyme analysis showed slight or no varation among accessions of jointed goatgrass (Hegde et al., 2002; Watanebe et al., 1994).

A band similar to $\gamma=45$ band, that is related to high quality gluten, was also observed in all of the studied populations (Fig. 1). This was conformed by Sofalian and Valizadeh (2009).

Cluster analysis of $17 \mathrm{~A}$. cylindrica populations (Fig. 2) using the similarity matrix of simple matching coefficient with complete linkage or furthest neighbors method separated populations into two groups. The first group included the C1, C4, C5, C10, C11, C12, C13, C14, C16 and $\mathrm{C} 17$ populations, whereas other populations aligned as the second group which indicating genetic diversity doesn't follow geographical distribution. Principle coordinate analysis showed that the first three components determined approximately $70 \%$ of total variance that it confirmed the cluster analysis grouping, too.

The results of discriminant analysis were completely justified two groups and confirmed the cutting point in cluster analysis. The mantel test between initial similarity matrix and the resulted cophenetic matrix of dendrogram showed that correlation coefficient between the matrices is 0.65 , indicating a more or less high efficiency of grouping.

Tab. 3. Among and within population genetic diversity of $A$. cylindrica

\begin{tabular}{cccc}
\hline \multirow{2}{*}{ Nei's gene diversity } & \multicolumn{3}{c}{ Gliadin band spectra regions } \\
\cline { 2 - 4 } & $\omega$ & $\gamma$ & $\beta$ \\
\hline Within populations & 0.0397 & 0.0662 & 0.0441 \\
Among populations & 0.0699 & 0.1023 & 0.1685 \\
Total & 0.1096 & 0.1685 & 0.2126 \\
\hline
\end{tabular}




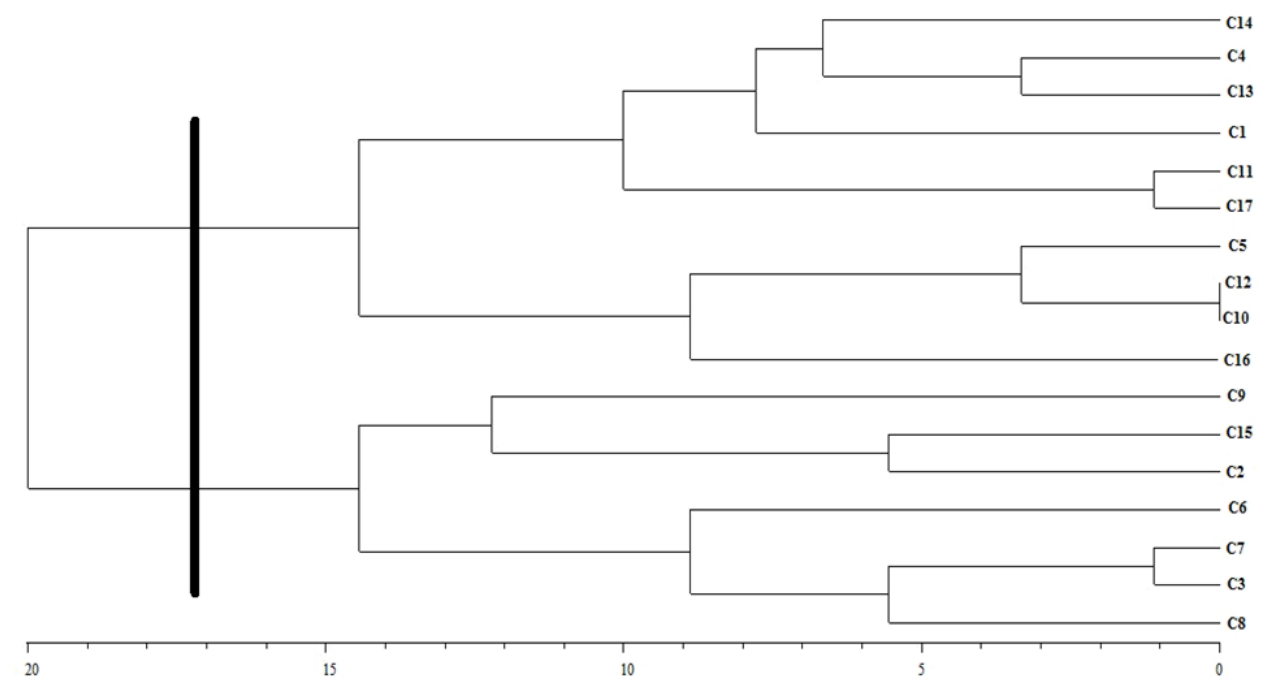

Fig. 2. Dendrogram of 17 A. cylindrica populations using complete linkage method in cluster analysis

\section{Conclusions}

Results obtained from gliadin patterns as a biochemical marker exhibited low within and among populations genetic diversity in $A$. cylindrica populations from northwest of Iran.

Although this genetic diversity was limited but it could be used in any quality improvement breeding programs. These results can be used for adoption of proper sampling strategies for germplasm conservation of this species. In addition, the most gliadin bands of $A$. cylindrica, at least with regard to mobility and electrophoretic position, shared with those of Bezostaya, from that, it can be used to study the genome affinity of these species.

\section{References}

Bietz JA, Huebner FR, Sanderson JE, Wall JS (1977). Wheat gliadin homology revealed through $\mathrm{N}$-terminal amino acid sequence analysis. Cereal Chem 54:1070-1083.

Carrillo JM, Rousset M, Qualset CO, Kasarda DD (1990). Use of recombinant inbred lines of wheat for study of associations of high molecular weight glutenin subunits alleles to quantitative triats. Theor Appl Genet 79:321-330.

El Bouhssini M, Benlhabib O, Nachit MN, Houari A, Bentika A, Nsarellah N, Lhaloui S (1998). Identification in Aegilops species of resistant sources to Hessian fly (Diptera: Cecidomyiidae) in Morocco. Genet Res Crop Evol 45: 343-345.

Farkhari M, Naghavi MR, Pyghambary SA, Sabokdast S (2007). Genetic variation of jointed goatgrass (Aegilops cylindrica Host) from Iran using RAPD-PCR and SDS-PAGE of seed proteins. Pak J Bio Sci 17:2868-2873.

Farooq S, Iqbal N, Asghar M, Shah TM (1992). Intergeneric hybridization for wheat improvement VI. Production of salt tolerant germplasm through crossing wheat (Triticum aestivum) with Aegilops cylindrical and its significance in practical agriculture. J Genet Plant Breed 46: 125-132.
Gianibelli MC, Larroque OR, MacRitchie F, Wrigley CW (2001). Biochemical, genetic, and molecular characterization of wheat endosperm proteins. Am Assoc Cereal Chem. Publication no C-2001-0926-010.

Gregova E, Hauptvogel P, Vorosvary G (2011). Diversity of seed storage protein patterns of slovak accession in jointed goatgrass (Aegilops cylindrica Host). Plant Genetic Resour 2:222-223.

Guadagnuolo R, Savova-Bianchi D, Felber F (2001). Gene flow from wheat (Triticum aestivum L.) to jointed goatgrass (Aegilops cylindrical Host.), as revealed by RADP and microsatellite markers. Theor Appl Genet 103:1-8.

Hegde SG, Valkoun J, Waines JG (2002). Genetic diversity in wild and weedy Aegilops, Amblyopyrum, and Secale species-a preliminary survey. Crop Sci 42:608-614.

Iriki N, Kawakami A, Takata K, Kuwabara T, Ban T (2001). Screening relatives of wheat for snow mold resistance and freezing tolerance. Euphytica 122:335-341.

Johnson BL (1967). Confirmation of the genome donors of $A e-$ gilops cylindrica using seed protein electrophoretic patterns. Nature 216:859-862.

Kenzevic D, Zeecevic V, Pavalovic M (1998). Genetic similarity of wheat cultivars according to gliadin allele composition. Proceedings of 9 th International wheat genetics symposium, 178-181 p.

Kozubo NA, Sozinov IA, Sozinov AA (2003). Recombination of geliadin genes of chromosome 1D in the common wheat hybrid carrying the introgression from Aegilops cylindrica. Plant Breed 122:86-88.

Kozubo NA, Sozinov IA, Sozinov AA (2004). Effect of introgression from Aegilops cylindrica Host on manifestation of productivity traits in winter common wheat $\mathrm{F}_{2}$ plants. Russian J Genet 40(12):1378-1382.

Mallory-Smith CA, Hansen J, Zemetra RS (1996). Gene transfer between wheat and Aegilops cylindrical, 441-445 p. In: Brown H, Cussans GW, Devine MD, Duke SO, Fernandez- 
Quintanilla C, Helweg A, Labrada R, Landes M, Kudsk P, Streibig JC (Eds.). Proc. of the Second Int. Weed Control Congr., Copenhagen. 25-28 June 1996. Dep. of Weed Control and Pesticide Ecology, Flakkebjerg, Denmark.

Metakovsky EV, Novoselskaya AY (1991). Gliadin allele identification in common wheat.1. Methodological aspects of the analysis of gliadin patterns by one-dimensional polyacrylamide gel electrophoresis. J Genet Breed 45:317-324.

Metakovsky EV, Novoselskaya AY, Sozinov AA (1984). Genetic analysis of gliadin components in winter wheat using twodimensional polyacrylamide gel electrophoresis. Theor Appl Genet 69:31-37.

Nei M (1978). Estimation of the average heterozygosity and genetics distance from a small number of individuals. Genetics 89:583-590.

Payne PI, Seeking SJA, Worland AW, Jarvis MG, Holt LM (1987). Allelic variation of glutenin subunits and gliadin and its effect on bread making quality in wheat analysis of F5 progeny from Chinese Spring. Cereal Sci 4:103-111.

Rashed MA, Abou-Deif MH, Sallam MAA, Aida Rizkalla A, Walaa Ramadan A (2007). Identification and prediction of the flour quality of bread wheat by gliadin electrophoresis. J Appl Sci Res 3(11):1393-1399.
Sofalian O, Valizadeh M (2009). Investigation of Seed Storage Proteins in some Wild Wheat Progenitors Using Sds-Page and Acid-Page. Not Bot Horti Agrobo 37(1):179-182.

Tsunewaki K (1996). Plasmon analysis as the counterpart of genome analysis, 71-299 p. In: Jauhar PP (Ed.). Methods of genome analysis in plants. CRC Press, Bota Raton, New York, London Tokyo.

Vorosvary G, Mar I, Holly L, Kissimon J (2000). Analysis of genetic polymorphisms in jointed goatgrass (Aegilops cylindrica) and annual wild rye (Secale sylvestre) populations from Hungary. Portugaliae Acta Biol 19:137-147.

Watanabe N, Mastui K, Furuta Y (1994). Uniformity of the alpha amylase isozymes of Aegilops cylindrica introduced into North America: comparison with ancestral Eurasian accessions, 215-218 p. In: Wang RRC, Jensen KB, Jaussi C (Eds). Proc 2nd Intl Triticeae Symp., Logan, UT, June 20-24.

Zemetra RS, Hansen J, Mallory-Smith CA (1998). Potential for gene transfer between wheat (Triticum aestivum) and jointed goatgrass (Aegilops cylindrica). Weed Sci 46:313-317. 